\title{
Perubahan Morfologi dan Anatomi Kalus Catharanthus roseus dengan Perlakuan Triptofan \\ (The morphological and anatomical changes on tryptophan-treated callus of Catharanthus roseus)
}

\author{
Dingse Pandiangan ${ }^{1)^{*}}$ \\ 1) Jurusan Biologi Fakultas MIPA Universitas Sam Ratulangi Manado \\ "E-mail korespondensi: dingsepan@yahoo.com
}

Diterima 5 Februari 2012, diterima untuk dipublikasikan 20 Februari 2012

\begin{abstract}
Abstrak
Penelitian tentang perubahan morfologi dan anatomi kalus Catharanthus roseus dengan pemberian perlakuan triptofan telah dilakukan. Penelitian ini bertujuan untuk melengkapi informasi tentang perubahan yang terjadi pada kalus khususnya struktur anatomi dan morfologi sel kalus Catharanthus roseus setelah diberi perlakuan prekursor triptofan 175 $\mathrm{mg} / \mathrm{L}$. Pengamatan anatomi kalus dilakukan dengan metoda Parafin yang didokumentasikan dengan mikroskop Nikon Halogen $100 \mathrm{~W}$ perbesaran $10 X 10$ dan difoto dengan camera Nikon DXM 1200F. Penampakan morfologi kalus didokumentasikan dengan camera digital Cannon. Hasil penelitian menunjukkan bahwa pertumbuhan kalus yang diberi perlakuan triptofan lebih lambat pada awalnya, namun bertahan hidup sampai 40 hari kultur. Kalus tanpa triptofan cepat bertumbuh pada awalnya sampai hari ke 18 kultur, setelah itu tidak ada pertumbuhan lagi. Setelah kultur 40 hari kultur, kalus dengan perlakuan triptofan tetap bertumbuh dengan baik sedangkan kontrol sudah rusak atau lisis. Struktur sel kalus perlakuan triptofan setelah 28 kali subkultur menunjukkan adanya penebalan dinding sel, sedangkan sel kalus kontrol mengalami lisis atau kerusakan sel.

Kata kunci: anatomi, Catharanthus roseus, kalus, morfologi, triptofan
\end{abstract}

\begin{abstract}
A research on the morphological and anatomical changes on tryptophan-treated callus of Catharanthus roseus was conducted. This study aimed to complete the information about the changes, particularly on anatomical and morphological structure of Catharanthus roseus callus cells after treatment of $175 \mathrm{mg} / \mathrm{L}$ precursor tryptophan. Anatomical observations was conducted using paraffin method, documented using a Nikon microscope with a $10 \times 10$ magnification and the photograph was taken using the Nikon DXM $100 \mathrm{~W}$ Halogen 1200F camera. The appearance of callus morphology was documented by Cannon digital camera. The results showed that the growth of tryptophantreated callus was slower at the beginning, but it survived by 40-day culture. Nontryptophan callus grew rapidly by 18-day culture and did not grow later on. Tryptophantreated callus for 40 days grew well, whereas control callus was damaged or lysis. The tryptophan-treated callus after 28 times subcultures showed cell wall thickening, whereas the control callus cells are lysis or damaged.
\end{abstract}

Keywords: anatomy, callus, Catharanthus roseus, morphology, tryptophan

\section{PENDAHULUAN}

Tapak dara (Catharanthus roseus

(L) G. Don) banyak dibudidayakan sebagai tanaman hias dan obat. Tanaman tapak dara ini berguna untuk mengobati hipertensi, diabetes, 
pendarahan akibat penurunan jumlah trombosit, eptelioma korionik, leukemia limfositik akut, leukemia, monositik akut, limfosarkoma dan sarkoma sel retikulum. Beberapa penelitian lain melaporkan bahwa sekitar 130 macam alkaloid telah diidentifikasi pada tanaman ini. Diantaranya adalah alkaloid anti kanker seperti vinblastin (VLB), vinkristin (VCR) dan leurosin.

Kultur kalus maupun jaringan (in
vitro) tanaman ternyata dapat memproduksi senyawa kimia berupa alkaloid dan sejenisnya yang tergolong metabolit sekunder (Vazquez-Flota et al. 1994, Kim et al. 1994). Beberapa penelitian menyatakan bahwa alkaloid tertentu dihasilkan lebih tinggi melalui kultur jaringan (kalus) dari pada kandungan tanaman induknya (Pandiangan et al. 2006). Dengan demikian sangat perlu menggunakan kultur jaringan pada pengembangan tapak dara ini untuk memproduksi suatu senyawa alkaloid. Penemuan ini menimbulkan harapan untuk menerapkan cara yang sama dalam skala besar terutama untuk memproduksi antara lain alkaloid anti kanker yang selama ini ditakuti.

Pandiangan et al. (2006) sudah melaporkan bahwa pendekatan penambahan prekursor sudah dilakukan. Perlakuan triptofan pada kalus tapak dara dapat meningkatkan kandungan katarantin sampai $950,536 \mu \mathrm{g} / \mathrm{g}$ berat kering (BK). Umumnya pada pertumbuhan kalus rendah menghasilkan kandungan katarantin yang lebih tinggi daripada pertumbuhan yang tinggi. Dari penelitian tersebut ditemukan pertumbuhan optimum adalah pada perlakuan $175 \mathrm{mg} / \mathrm{L}$ prekursor triptofan. Moreno-Valenzuela (1998), juga melaporkan bahwa pada sel yang mengalami spesialisasi dan diferensiasi menghasilkan metabolit sekunder yang tinggi pada kultur in vivo. Sel yang mengalami diferensiasi menunjukkan pertumbuhan yang lebih lambat dari pada yang undiferensiasi. Disamping itu, Girod and Zryd (1991) melaporkan bahwa morfologi sel pada kultur kalus bit merah mempengaruhi akumulasi pigmen betalain. Penambahan prekursor triptofan dapat meningkatkan kandungan katarantin (Pandiangan et al 2006) mungkin juga dapat mengubah morfologi dan anatomi kalus. Oleh karena itu dilakukan penelitian ini untuk mengetahui perubahan morfologi dan anatomi kalus C. roseus yang diberi perlakuan triptofan.

\section{METODE Bahan dan Medium}

Bahan penelitian yang digunakan adalah daun dari tunas apikal $C$. roseus yang tumbuhkan di Laboratorium. $C$. roseus yang digunakan sebagai sumber eksplan $C$. roseus berbunga putih. Medium yang digunakan adalah medium Murashige dan Skoog (MS), yang dilengkapi dengan zat hara makro, mikro, vitamin, zat pengatur tubuh, sukrosa dan agar-agar. Medium disterilkan dengan otoklaf $15 \mathrm{lb} / \mathrm{inc}^{2}$ dengan suhu $121^{\circ} \mathrm{C}$ selama 15 menit.

\section{Induksi Kalus}

Induksi kalus mengikuti metoda Pandiangan dan Nainggolan (2006). Eksplan daun C. roseus disterilkan terlebih dahulu sebelum dikulturkan pada medium induksi kalus. Sterilisasi dilakukan dengan alkohol $75 \%$ dan $\mathrm{Na}$ hipoklorit $2 \%$ selama 15 menit yang dilakukan 3 kali secara bertahap. Eksplan yang sudah steril dikulturkan dalam medium MS dengan kombinasi zat pengatur tumbuh 2,4-D $2 \mathrm{mg} / \mathrm{L}$ dan Kinetin 0,2 mg/L. . Subkultur dilakukan setiap 3 minggu, selama 2 bulan untuk memperbanyak kalus dan membuat kalus kompak semakin meremah pada kultur kalus yang berulang-ulang. 


\section{Perlakuan Triptofan pada Kultur Kalus}

Subkultur kalus pada media MS dengan perlakuan triptofan $175 \mathrm{mg} / \mathrm{L}$ dilakukan langsung pada saat subkultur kedua. Setiap perlakuan dibuat 4 ulangan. Berat inokulum yang digunakan dalam kultur dalam adalah $2 \mathrm{~g}$ kalus. kalus ditimbang secara aseptik dalam Laminar air flow ketika sedang subkultur. Medium yang disiapkan sekitar 16 botol kultur.

\section{Pengamatan Morfologis dan Anatomi Kalus}

Penampakan secara morfologi kalus diamati secara visual. Hasil pengamatan didokumentasikan dengan menggunakan kamera digital Cannon. Pengamatan anatomi didokumentasikan dengan menggunakan mikroskop Nikon Halogen 100 W dengan perbesaran $10 \times 10$ yang difoto dengan camera digital Nikon DXM 1200F. Anatomi kalus diamati dengan metoda parafin.

\section{HASIL DAN PEMBAHASAN}

Pengamatan morfologi dan pertumbuhan kalus secara visual menunjukkan bahwa pertambahan besar kalus kontrol cepat pada awalnya sampai hari ke-18 (Gambar 1). Setelah itu mengalami pencoklatan dan tidak ada pertambahan ukuran secara visual. Namun pada perlakuan triptofan pada awalnya (sampai hari 18) lambat pertambahan ukuran kalus, tapi terus bertahan dan sampai hari ke-28 dan masih tumbuh baik seperti Gambar 2. Bahkan kalus sampai pada hari ke-40 kultur juga menunjukkan penampakan yang serupa dengan Gambar tersebut. Oleh karena itu pada hari ke-40 setelah kultur dalam perlakuan triptofan, menghasilkan berat basah yang lebih tinggi seperti pada Pandiangan dan Nainggolan (2006).

Pada Gambar 1 terlihat bahwa kalus kontrol $(\mathrm{K})$ yang diamati pada hari ke-18 setelah subkultur menunjukkan pertumbuhan yang lebih cepat dibandingkan dengan kalus perlakuan pada triptofan. Tapi kemudian kalus kontrol ini akan terlebih dahulu mengalami fase penurunan atau penuaan dibandingkan kalus perlakuan. Kalus perlakuan dapat bertahan bahkan sampai lebih dari 40 hari. Pada minggu ketiga (hari ke 21) kalus kontrol mulai kelihatan berwarna coklat (nekrotis) sepertinya selselnya mengalami kerusakan. Namun kalus $T$ masih tetap berwarna putih kekuningan atau nampak masih bertumbuh baik sampai hari ke-28 kultur (Gambar 2).

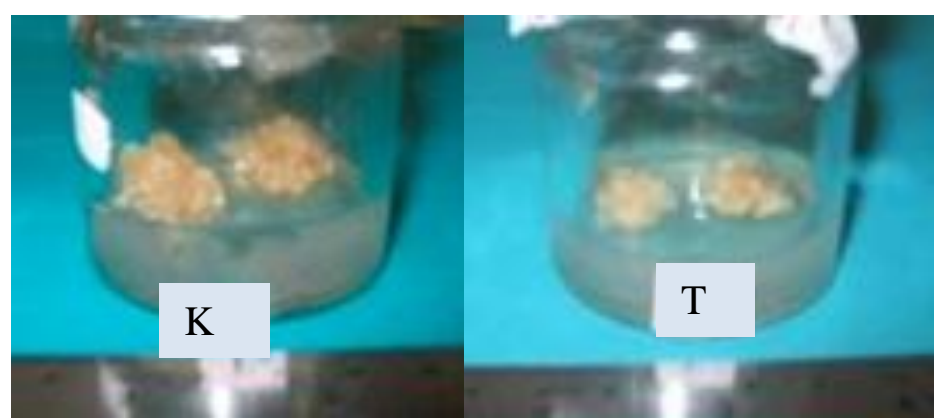

Gambar 1. Penampakan kalus Catharanthus roseus yang diberi perlakuan triptofann (T) dan kontrol $(\mathrm{K})$ yang diamati pada hari ke-18 setelah subkultur 

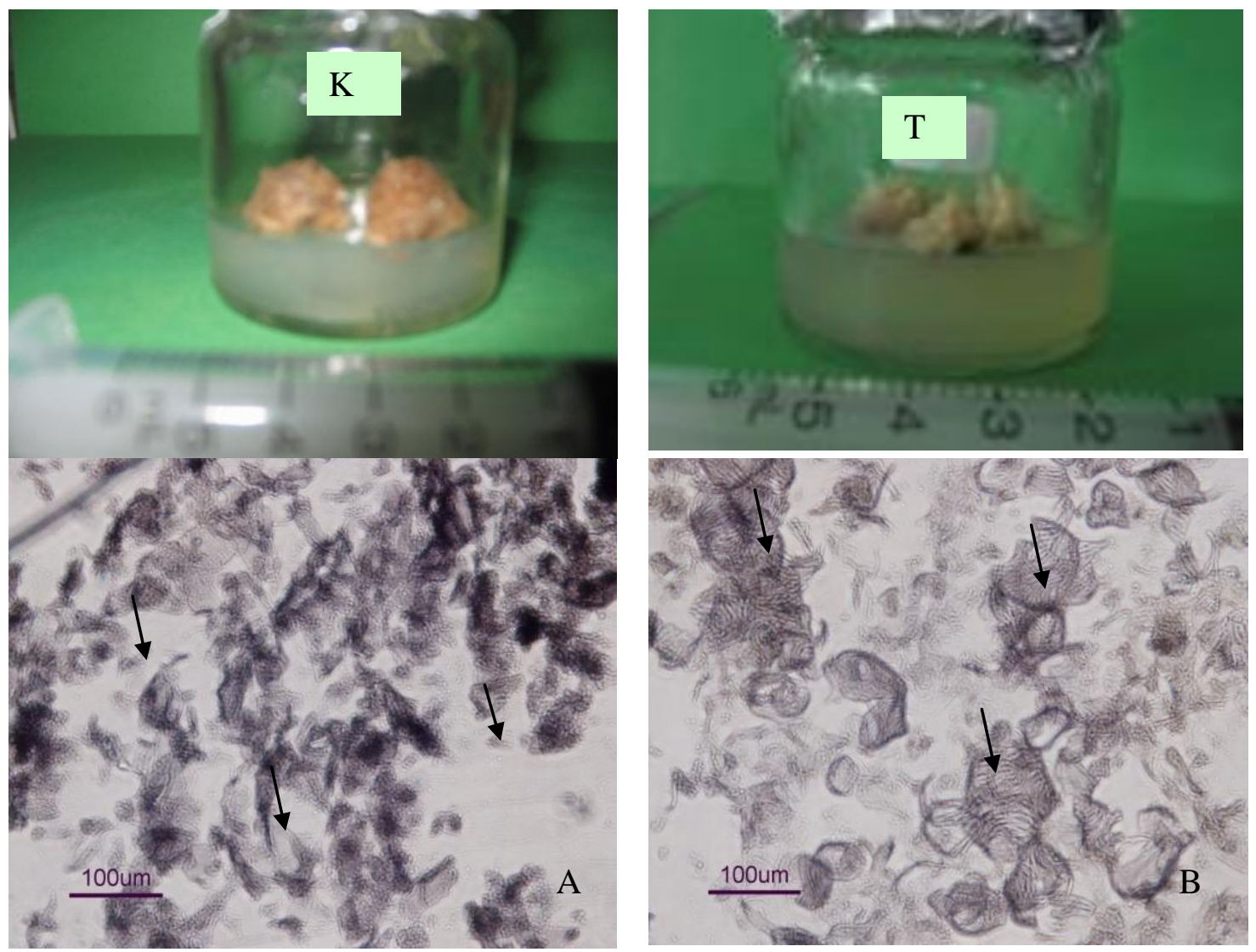

Gambar 2. Penampakan kalus $C$. roseus setelah hari ke-28 disubkultur pada medium perlakuan triptofan. $\mathrm{K}=$ kontrol, nampak warna kecoklatan. $\mathrm{T}=$ perlakuan triptofan $200 \mathrm{mg} / \mathrm{L}$ dengan kalus berwarna putih kekuningan. $\mathrm{A}=$ penampakan sayatan kalus $\mathrm{K}$ dengan sel lisis $(\downarrow) . B=$ penampakan sayatan kalus T dengan penebalan dinding sel ( 4$)$

Hasil analisis anatomi kalus tanpa triptofan (kontrol $=\mathrm{K}$ ) menunjukkan bahwa sel nampak pecah atau lisis (Gambar 2A). Kalus $T$ atau perlakuan triptofan menunjukkan bahwa sel-selnya banyak yang mengalami penebalan. Sel yang menebal tersebut merupakan respon terhadap perlakuan triptofan. Penampakan selnya mirip dengan sel trakeid dan terlihat banyak jumlahnya (Gambar 2B). Menurut Rompas (1998) bahwa sel-sel penghasil metabolit sekunder alkaloid pada $C$. roseus adalah latisifer. Proses perkembangannya menunjukkan sel-selnya memanjang dan mengalami penebalan dinding yang mempunyai sifat-sifat yang sama dengan xilem (Darsini 2001). Sifat sel latisifer yang sangat menonjol dalam hal ini adalah adanya penebalan dinding selnya. Oleh karena penebalan dinding sel juga dapat menyebabkan pembelahan sel berkurang. Disamping itu sel kalus yang diberi perlakuan triptofan mengalami penebalan dingding yang mengakibatkan sel-sel tersebut tidak cepat lisis atau kerusakan kalus. Medium yang lama tentu sudah mengalami pengurangan kandungan nutrisi dan perubahan tekanan osmosis akibat pertumbuhan kalus (Moreno-Valenzuela et al. 1999). Oleh karena penebalan yang terjadi sel T mempunyai pertahanan terhadap perubahan tekanan osmosis dalam 
medium (Taiz and Zeiger 2002), sehingga sel kalus bertahan lama dan bertumbuh baik. Di samping itu triptofan yang berlebih dalam media dapat dikonversi oleh sel tumbuhan menjadi asam piruvat dan asetil ko-A pada katabolisme sel (Lehninger 1990), sehingga kekurangan nutrisi dapat diatasi dan dapat memperpanjang waktu kultur.

Pola pertumbuhan kalus (data pada Pandiangan 2006) tersebut menunjukkan bahwa $175 \mathrm{mg} / \mathrm{L}$ triptofan yang ditambahkan ke dalam media menghasilkan kalus dengan berat basah tertinggi. Hal ini menunjukkan bahwa perlakuan prekursor triptofan terhadap pertumbuhan kalus mempunyai konsentrasi yang optimum. Perlakuan prekursor triptofan mempunyai mekanisme penghambatan feedback pada konsentrasi yang semakin tinggi dari konsentrasi triptofan $200 \mathrm{mg} / \mathrm{L}$ (Taiz and Zeiger 2002). Tetapi juga mempunyai mekanisme induksi terhadap pertumbuhan pada konsentrasi triptofan 100 sampai $200 \mathrm{mg} / \mathrm{L}$.

Pengamatan secara kuantitatif lebih menguatkan pengamatan kualitatif sebelumnya pada penelitian sebelumnya. Melanjutkan hasil sebelumnya bahwa bahwa kalus kontrol lebih cepat mengalami penuaan (senescens) dari kalus perlakuan triptofan. Hal ini dapat dibuktikan dari naiknya berat basah atau pertumbuhan kalus setelah 40 hari kultur pada perlakuan triptofan $175 \mathrm{mg} / \mathrm{L}$. Di samping itu nutrisi yang ditambahkan melalui triptofan merupakan nutrisi tambahan dan merupakan cadangan nutrisi pada pertumbuhan kalus (MorenoValenzuela et al. 1999). Faktor komposisi media sangat mempengaruhi aktivitas enzim yang mempengaruhi pertumbuhan dan kandungan alkaloid (Merilon et al. 1986).

Zhao et al. (2001), melaporkan dengan penambahan triptofan $300 \mathrm{mg} / \mathrm{l}$ dan 500 mg/l pada kultur kalus kompak dari $C$. roseus tidak menekan pertumbuhan kalus atau pertumbuhannya tetap normal sama dengan kontrol (tanpa triptofan) meskipun kandungan alkaloidnya meningkat. Ada perbedaan antara hasil penelitian ini dengan Zhao et al. (2001). Hasil penelitian ini menunjukkan adanya pengaruh terhadap pertumbuhan kalus. Zhao et al. (2001), melaporkan bahwa kandungan katarantin meningkat dengan penambahan triptofan $300 \mathrm{mg} / \mathrm{l}$ dan $500 \mathrm{mg} / \mathrm{l}$ pada kultur kalus kompak dari $C$. roseus. Pengaruh triptofan terhadap kultur itu bisa meningkatkan atau menurunkan kandungan alkaloid tergantung tipe kultur dan spesies yang digunakan. Kalau pada kalus meningkatkan tapi pada kultur lain bisa saja menurunkan atau sebaliknya.

\section{KESIMPULAN}

Pertumbuhan kalus $C$. roseus yang diberi perlakuan triptofan lebih lambat pada awalnya, namun bertahan hidup sampai 40 hari kultur. Kalus tanpa triptofan cepat bertumbuh pada awalnya sampai hari ke 18 kultur, setelah itu tidak ada pertumbuhan lagi. Setelah kultur 40 hari kultur, kalus dengan perlakuan triptofan tetap bertumbuh dengan baik sedangkan kontrol sudah rusak atau lisis. Struktur sel kalus perlakuan triptofan setelah 28 kali subkultur menunjukkan adanya penebalan dinding sel, sedangkan sel kalus kontrol mengalami lisis atau kerusakan sel.

\section{UCAPAN TERIMA KASIH}

Diucapkan terima kasih kepada pimpinan dan staf SITH ITB Bandung yang memberikan kesempatan untuk menggunakan alat mikroskop Nikon Halogen $100 \mathrm{~W}$ dengan camera digital Nikon DXM 1200F sehingga tulisan ini dapat dipublikasikan. Demikian juga dengan Dr. Rizkita Rahmi Esyanti diucapkan terima kasih atas kerjasamanya melalui penelitian Hibah Pekerti. 


\section{DAFTAR PUSTAKA}

Girod PA and Zryd JP (1991) Secondary metabolism in culture red beet (beta vulgaris L.) cells: differentional regulation of betaxanthin and betacyanin biosynthesis. Plant Cell Tissue Organ Culture 25:1-12

Kim SW, Jung KH, Kwak SS, and Liu JR (1994) Relationship between cell morphology and indole alkaloid production in suspension cultures of Catharanthus roseus. Plant Cell Report 14:23-26

Merillon JM, Doireau P, Guiilot A, Chonieux JC, and Rideau $M$ (1986) Indole alkaloid accumulation and tryptophan decarboxylase activity in Catharanthus roseus cells cultured in three different media. Plant Cell Reports 5:23-26

Moreno-Valenzuela O, Coello-Coello J, Loyola-Vargas VM and VazquezFlota F (1999). Nutrient consumption and alkaloid accumulation in a hairy root line of Catharanthus roseus. Biotechnology Letters 21: 10171021

Darsini NN (2001) Perkembangan latisifer pada kultur kalus Catharanthus roseus (L.) G. Don. Tesis ITB Bandung.

Moreno-Valenzuela OA, Galaz-Avalos RM, Minero-Garcia Y, LoyolaVargas VM (1998) Effect of diffrentiation on the regulation of indole alkaloid production in
Catharanthus roseus hairy roots. Plant Cell Reports 18: 99-104

Pandiangan D, Nainggolan N (2006) Produksi alkaloid dari kalus tapak dara. Jurnal IImiah Sains 6: 48-54

Pandiangan D (2006) Respons Pertumbuhan Kalus Catharanthus roseus yang diberi perlakuan triptofan. Jurnal Biotika 5:49-56

Pandiangan D, Rompas D, Aritonang $\mathrm{H}$, Esyanti RR, Marwani E ( 2006) Pengaruh triptofan terhadap pertumbuhan dan kandungan katarantin pada kultur kalus $C$. roseus. Jurnal Matematika dan Sains 11:111-118

Rompas DR (1998) Asal-usul, perkembangan dan penyebaran Latisifer pada tumbuhan tapak dara (Catharanthus roseus (L) G.Don). Tesis ITB Bandung

Taiz L and Zeiger E (2002) Plant physiology, 3rd ed. Sinauer Associates, pp 423-460

Vazquez-Flota $F$, Moreno-Valenjuela $O$, Miranda-Ham ML, Coello-Coello J, and Loyola-Vargas VM (1994) Catharanthine and ajmalisine synthesis in Catharanthus roseus hairy root cultures. Plant Cell, Tissue and Organ Culture 38: 273-279

Zhao J, Hu Q, Guo YQ, Zhu WH (2001) Effects of stress factors, bioregulators, and synthetic precursors on indole alkaloid production in compact callus clusters cultures of Catharanthus roseus. Appl Microbiol Biotechnol 55:693-698. 